\title{
Menjaga Kesehatan Mental Dengan Pengelolaan Kecemasan di Masa Pandemi Covid 19
}

\section{Maintaining Mental Health With Anxiety Management During the Covid 19 Pandemic}

\author{
Sairah* \\ Fakultas Psikologi, Universitas Medan Area, Indonesia
}

Disubmit: 24 Oktober 2021; Diproses: 26 Oktober 2021; Diaccept: 12 November 2021; Dipublish: 02 Desember 2021

*Corresponding author: E-mail: sairahmpsi@gmail.com

\begin{abstract}
Abstrak
Corona Virus Deasease - 19 (Covid-19) merupakan sebuah penyakit baru yang sedang dialami di seluruh negara. Penyakit ini diyakini sebagai penyakit berbahaya bagi manusia dikarenakan penyebarannya yang cepat, serta menyerang saluran pernapasan manusia. Oleh karena itu, WHO sebagai organisasi kesehatan dunia membuat sebuah kebijakan yakni membatasi mobilitas masyarakat untuk keluar rumah, memakai masker, serta menjaga kebersihan diri sebagai pencegahan terhadap virus Corona (2019, WHO). Penyebaran Pandemi COVID 19 di seluruh dunia tidak hanya berdampak pada kesehatan fisik tetapi juga kesehatan mental. Salah satu dampak pandemi terhadap kesehatan mental yaitu perasaan cemas akan terpapar virus dan ketidakpastian kondisi selama pandemic. Kecemasan perlu dikelola dengan baik agar tetap dapat membuat kewaspadaan, namun tidak berlebihan sehingga menyebabkan gangguan kesehatan jiwa yang lebih buruk. Tulisan ini bertujuan untuk menjelaskan bagaimana mengelola kecemasan di masa pandemic bagi masyarakat dengan pendekatan sttudi literature. Dari perspektif psikologi ini penulis menyimpulkan bahwa mengelola cemas pada tingkat proporsional, adalah hasil dari persepsi situasi yang berulang. Itu pemilihan informasi yang diterima selama pandemic adalah kunci untuk mengelola kecemasan. Selanjutnya, beradaptasi dengan perubahan yang terjadi sehingga bisa melalui hidup sehat di tengah pandemi.
\end{abstract}

Kata Kunci: COVID 19; Kecemasan; Kesehatan Mental

\begin{abstract}
Corona Virus Disease 19 is a new disesase that is being experienced throughout the country. This disease is believed to be a dangerous disease for humans due to its rapd spread, and attacks the human respiratory tract. Therefore, WHO as a world health organization has made a policy that is to limit the mobility of people to leave the house, wear masks, and maintain personal hygiene as a prevention againt the corona virus (2019, WHO). The spread of the COVID 19 pandemic aound the world has not only had an impact on physical health but also mental health. One of the impacts of the pandemic on mental health is the feeling of anxiety abaout being exposed to the virus and the uncertainty of conditions during the pandemic. Anxiety needs to be managed properly so that it can still create vigilance, but not excessively so that it causes worse mental heslth disorder. This paper aims to explain how to manage anxiety during a pandemic for the community with a literature study approach. From this psychological perspective the authors conclude that managing anxiety on a proportional level, is the result of repeated perception of the situation. The selection of information received during a pandemic is key to managing anxiety. Furthermore, adapting to the changes that occur so that they can go through a healthy life in the midset of a pandemic.
\end{abstract}

Keywords: Anxiety; Covid 19; Mental Health

DOI: https://doi.org/10.51849/j-p3k.v2i3.123

\section{Rekomendasi mensitasi :}

Sairah (2021), Menjaga Kesehatan Mental Dengan Pengelolaan Kecemasan di Masa Pandemi Covid-19. Jurnal Penelitian Pendidikan, Psikologi dan Kesehatan (J-P3K), 2 (3): 275-284. 


\section{PENDAHULUAN}

Pandemi virus corona yang terjadi di seluruh dunia, termasuk Indonesia, berdampak pada semua bidang kehidupan manusia. Covid Virus Deasease - 19 adalah penyakit (wabah) baru yang sedang melanda seluruh negeri. Penyakit ini dianggap sebagai penyakit berbahaya bagi manusia karena penyebarannya yang cepat, dan menyerang saluran pernapasan manusia. Selanjutnya, WHO sebagai asosiasi kesejahteraan dunia membuat aturan yang membatasi keleluasaan individu untuk keluar rumah, memakai masker, dan menjaga kebersihan individu sebagai pencegahan terhadap Covid (WHO, 2020) dan setiap area pun mengalami perubahan standar.

Jumlah kasus positif virus corona di Indonesia hingga 17 Juli 2021 tercatat bertambah 51.952. Selanjutnya, kasus positif Covid-19 total menjadi 2.832.755 dengan jumlah 72.489 orang meninggal karena virus corona (Liputan6, 2021). Besarnya angka kematian tidak hanya menimbulkan gejala dan penyakit yang sebenarnya, tetapi juga secara signifikan mempengaruhi kesejahteraan yang mencakup kesejahteraan psikologis, kemudian, pada saat itu, dikombinasikan dengan strategi pemerintah seperti penghapusan fisik dan pembatasan wilayah. Latihan (PPKM) untuk beradaptasi dengan virus Corona, bagi individu tertentu memiliki akibat yang merugikan, misalnya gelisah, putus asa menghadapi tekanan. Selain itu, virus corona membuat masyarakat takut untuk memeriksakan diri ke Rumah Sakit (Sesilia, 2020).

Ketegangan selama pandemi di seluruh dunia telah menyebabkan beberapa masalah seperti ketakutan dan kecemasan, perubahan pola istirahat dan makan, merasa putus asa dan mengalami masalah konsentrasi, kelelahan, stres karena terus-menerus di rumah dan munculnya masalah psikomatis. (Ilpaj \& Nurwati, 2020)

Corona virus dikaitkan dengan indikasi mental dan neurologis termasuk delirium atau ensefalopati, agitasi, stroke, meningo-ensefalitis, gangguan indera penciuman dan pengecapan, kecemasan, ketegangan, kesuraman dan masalah istirahat. Sebagian besar peristiwa terkait corona, manifestasi neurologis telah diperhitungkan bahkan tanpa efek samping pernapasan. Kegelisahan dan keputusasaan memberikan kesan normal di antara individu yang dirawat di rumah sakit karena Corona virus.

Tindakan pencegahan dan pengobatan adalah cara untuk pelaksanaan dalam kesejahteraan dan administrasi daerah. Tindakan pencegahan terbaik meliputi (1) melakukan kebersihan tangan menggunakan pembersih tangan jika tangan tidak tampak kotor atau mencuci tangan dengan pembersih jika tangan terlihat kotor, (2) berusaha untuk tidak memegang mata, hidung dan mulut, (3) menerapkan perilaku batuk atau bersin dengan menutup hidung dan mulut dengan lengan atas atau tisu dan membuang tisu ke tempat sampah, (4) menggunakan masker medis jika memiliki gejala pernapasan dan melakukan kebersihan tangan setelah melepas masker dan (5) menjaga jarak (tidak kurang dari 1 meter) dari individu yang mengalami gangguan pernapasan (Kemenkes RI, 2020). 
Antisipasi utama bagi orang yang dalam bahaya, ialah mereka harus membatasi pergerakan sampai jangka waktu inkubasi, kemudian antisipasi lainnya yaitu membangun daya tahan tubuh dengan cara pemberian makanan yang baik, mencuci tangan lebih rajin, menggunakan masker jika dalam lokasi bahaya, aktif bekerja dan berolahraga, istirahat yang cukup dan makanan disiapkan sampai matang dan bila merasa tidak enak badan cepat pergi ke klinik medis rujukan untuk dinilai (Handayani, Diah, \& dkk, 2020).

Pemahaman tentang kesejahteraan emosional tidak dapat dipisahkan dari pemahaman tentang kesejahteraan dan penyakit yang fisik, beberapa penelitian yang berbeda telah menemukan hubungan antara kesehatan fisik dan psikologis orang di mana orang-orang dengan keluhan medis menampilkan masalah mental sampai ke tingkat gangguan mental dan begitu pula bagi orang dengan masalah mental juga menunjukkan masalah kesehatan fisik (Dewi, 2012).

Kesejahteraan psikologis adalah kondisi individu yang dibebaskan dari semua jenis indikasi masalah mental. Orang yang sehat secara mental akan benar-benar bekerja secara normal sepanjang kehidupan sehari-hari dan dapat menyesuaikan diri untuk menghadapi masalah sepanjang hari dengan memanfaatkan kapasitas penanganan tekanan atau stres (Putri, Wibhawa, Gutama, Indonesia, Mental, \& Masyarakat, 2015). Kesejahteraan emosional adalah sesuatu selain masalah psikologis. Unsur positif dari kesehatan mental ditegaskan oleh WHO yang dinyatakan dalam konstitusinya bahwa kesehatan adalah kondisi lengkap dari kesejahteraan fisik, mental dan sosial dan bukan hanya tidak ada penyakit atau sakit. Gagasan kesejahteraan psikologis terdiri dari kemakmuran, self-efficacy, kemandirian, kemampuan dan pengakuan untuk menghadirkan potensi intelektual dan emosional (WHO, Investing in Mental Health, 2003). Penyakit psikologis yang paling terkenal adalah kecemasan dan masalah depresi. Pada batasnya, individu yang memiliki rasa keputusasaan (depresi) tidak akan dapat bangun atau menangani diri mereka sendiri dengan benar dan individu dengan masalah kegelisahan tertentu tidak akan dapat keluar dari rumah atau mungkin memiliki kebiasaan impulsif untuk membantu mengurangi ketakutan (Departement of Health Australia, 2017).

Seperti yang ditunjukkan oleh WHO (2020) munculnya pandemi menyebabkan tekanan pada berbagai tingkat masyarakat. Meski sejauh ini belum ada survei yang efisien tentang pengaruh virus corona terhadap kesejahteraan psikologis, berbagai pemeriksaan yang diidentifikasi terkait pandemi justru berdampak pada kesehatan emosional korban (Kemenkes RI, 2020).

Pada tanggal 10 Oktober 2020 dalam rangka memperingati Hari Kesehatan Mental Sedunia, WHO menyelenggarakan penelitian tentang kesehatan emosional dan mengidentifikasi kondisi dunia yang saat ini menghadapi pandemi Corona virus. Hasil penelitian menunjukkan bahwa banyak negara melaporkan peningkatan penggunaan layanan kesehatan mental, sehingga ditarik kesimpulan bahwa Corona virus mempengaruhi kesejahteraan psikologis. 
Namun, kesehatan psikologis dihiraukan dalam rencana cepat tanggap pandemi Covid, meskipun perspektif kesehatan emosional hampir sama pentingnya dengan kesehatan fisik. Seperti yang ditunjukkan oleh penelitian, pada dasarnya 83\% dari 130 negara telah mementingkan kesehatan psikologis untuk penanganan mereka dalam mengelola pandemi (WHO, 2020). Ketakutan, khawatir, dan stres adalah reaksi normal terhadap bahaya yang dirasa atau nyata dan ketika dihadapkan pada kerentanan atau ketidakjelasan (WHO, 2020).

Pandemi COVID-19 merupakan peristiwa non-alam yang dapat berdampak pada masalah kesehatan mental dan psikososial (Kemenkes RI, 2020). Selama pandemi virus corona, reaksi keseluruhan dari individu yang secara langsung atau tidak langsung terkena dampak adalah ketakutan menjadi sakit dan meninggal, tidak memiliki keinginan untuk datang ke kantor perawatan medis yang terinspirasi oleh ketakutan paranoid yang akan ternoda saat ditangani, takut kehilangan pekerjaan mereka karena mereka tidak bisa bekerja selama pengasingan dan dikeluarkan dari pekerjaan, takut dijauhi oleh penduduk di lingkungan atau terisolasi karena berhubungan dengan penyakit, merasa lemah untuk mengamankan keluarga dan takut kehilangan karena penyebaran infeksi, takut dikucilkan dari keluarga karena aturan isolasi, tidak ingin untuk menangani anak-anak kecil yang terpisah dari orang lain atau terisolasi dan individu dengan cacat atau individu yang lebih tua karena takut terkontaminasi, merasa tidak berdaya, bosan, terpencil dan putus asa (Committee, 2020).

Penjelasan yang tidak wajar terhadap data tentang Covid-19 dapat memicu kecemasan, kekhawatiran, dan stres. Sehingga, tidak mengherankan jika tubuh merasakan gejala seperti Coronavirus setelah mendapatkan data yang diidentifikasi dengan efek samping dari infeksi Covid. Indikasi yang tampak sebenarnya adalah gejala gangguan psikosomatis yang beberapa di antaranya menunjukkan misalnya, sesak napas yang merupakan gejala penyakit virus corona. Psikosomatik adalah masalah atau penyakit dengan indikasi yang muncul seperti penyakit fisik yang disebabkan oleh variabel mental atau peristiwa psikososial tertentu. Hal ini karena tidak adanya fleksibilitas dalam mengelola tekanan. Psikosomatik dapat terjadi melalui siklus emosi sebagai tekanan yang tidak dapat disesuaikan seperti yang diharapkan (Sofia, 2020).

\section{METODE PENELITIAN}

Penulisan ini menggunakan metode deskriptif atas data-data yang dikaji berdasarkan literatur yang terkait dengan masalah kajian. Penulis melakukan komparasi antara literatur dengan pengetahuan. Diantara literatur yang digunakan berupa buku, jurnal, dan artikel di media sosial yang berkaitan dengan kesehatan mental dan pengelolaan kecemasan di masa pandemik ini (Ilpaj \& Nurwati, 2020).

Sistematika yang digunakan peneliti dalam penulisan penelitian ini (Zed, 2014), diantaranya ialah: a) mencari kesamaan (Compare) yaitu teknik melakukan review dengan cara mencari kesamaan diantara beberapa literatur \& 
diambil kesimpulannya; b) memberikan pandangan (Criticize) yaitu teknik melakukan review dengan membuat pendapat sendiri terhadap sumber yang dibaca; c) membandingkan (Synthesize) yaitu teknik melakukan review dengan menggabungkan beberapa sumber menjadi sebuah ide baru; d) meringkas (Summarize) yaitu teknik melakukan review dengan menulis kembali sumbernya dengan kalimat sendiri.

\section{HASIL DAN PEMBAHASAN}

Penyakit COVID-19 atau disebut juga Coronavirus Disease saat ini menjadi pandemi di hampir semua negara di planet ini. Wabah pandemi ini memiliki pengaruh buruk terhadap kekuatan fisik dan mental orang dan masyarakat (Banerjee, 2020). Sesuai Brooks et al. (2020), beberapa efek mental selama pandemi ialah masalah stres pasca-trauma (post-traumatic stress disorder), bingung, gelisah, frustasi, takut terkontaminasi, susah tidur dan perasaan rentan. Memang, bahkan beberapa terapis dan psikolog mencatat bahwa hampir berbagai masalah mental ringan hingga ekstrem dapat terjadi dalam kondisi pandemi ini. Para ahli telah sepakat bahwa kesehatan fisik dan psikologis saling terikat yang harus diawasi dengan cara yang layak. Keharmonisan antara kesehatan fisik dan psikologis selama pandemi juga menjadi fokus bagi pejabat publik.

Kementerian Kesehatan telah memberikan panduan Dukungan Kesehatan Jiwa Dan Psikososial (DKJPS) selama masa pandemi COVID-19. Berdasarkan pengaturan Badan Kesehatan Dunia (WHO), buku ini merupakan salah satu aturan bagi pekerja kesehatan dalam memberikan bantuan kesejahteraan emosional dan dukungan psikososial bagi Orang Sehat, Orang Dengan Pantauan (ODP), Orang Tanpa Gejala (OTG) , Pasien Dengan Pengawasan (PDP), Pasien Coronavirus, dan Kelompok yang lemah. Bila menilik struktur usia masyarakat, maka kelompok rawan yang akan terkena pengaruh di kesehatan mental dan psikososial akibat penyakit Coronavirus ialah wanita, anak-anak dan remaja, dan orang tua (lansia).

Dikutip dari salah satu hasil kaji cepat dari Survei Ketahanan Keluarga selama pandemi yang dilaksanakan oleh Institut Pertanian Bogor (IPB), dari 66\% responden wanita menikah didapat hasil bahwa masalah mental yang paling sering dialami ialah kecemasan dan kegelisahan (50,6 \%), mudah sedih (46,9\%), dan kesulitan konsentrasi (35,5 \%) (Sunarti, 2020). Kondisi ini patut diwaspadai mengingat wanita memiliki peranan penting dalam mengurus keluarga. Namun, anak-anak dan remaja pun tak luput dari pengaruh kebijakan pembatasan penyebaran virus sehingga dilakukan sistem pembelajaran jarak jauh. Keterbatasan ruang untuk berkembang dan tidak adanya kolaborasi dengan teman sebaya di masa pandemi dapat memengaruhi kesehatan emosional mereka. Begitu pula dengan kelompok yang lebih tua. Kerentanan lansia disebabkan oleh siklus degeneratif yang menyebabkan menurunnya daya tahan tubuh sehingga lansia tidak berdaya terhadap infeksi dan penyakit, termasuk COVID-19.

Di tengah pandemi yang penuh dengan kerentanan, mudah bagi orang tua untuk merasakan kecemasan berlebihan dimana memengaruhi keadaan fisik 
mereka. Keadaan yang begitu kompleks dan menyusahkan mental dari setiap kelompok umur membutuhkan perhatian dan penanganan yang cepat agar tidak menjadi masalah mental yang lebih serius. Perkumpulan-perkumpulan rentan yang dimaksud di atas merupakan gambaran dari keadaan masyarakat saat ini.

WHO (2020) dan spesialis kesehatan umum membuat serangkaian pesan yang dapat digunakan dalam korespondensi untuk membantu kesehatan mental dan kesejahteraan psikososial selama pandemi Coronavirus. Aturan untuk semua orang, diantaranya (1) ketika merujuk pada orang dengan COVID-19, tidaklah menganggap penyakit itu dengan etnis tertentu, berikan empati pada semua orang yang terkena dampak karena mereka pantas menerima dukungan, kasih sayang dan kebaikan, (2) jangan menyebut individu dengan penyakit seperti kasus COVID-19, korban, keluarga Coronavirus atau orang yang lemah, individu dengan Coronavirus, individu yang dirawat karena Coronavirus dan setelah sembuh dari Coronavirus, sangatlah penting untuk memisahkan individu dari identitas COVID-19 untuk mengurangi prasangka, (3) mengurangi menonton, membaca atau memperhatikan berita tentang virus corona yang membuat terekan atau kesedihan, mencari data hanya dari sumber terpercaya sebab kebenaran dapat mengurangi dan membatasi kecemasan, (4) melindungi diri dan mendukung individu lain, kemudian gotong royong sebagai kesatuan kelompok dalam membantu membuat kebersamaan dalam penanganan virus corona, (5) temukan kesempatan untuk membagikan cerita-cerita positif dan penuh harapan serta gambaran positif dari individu yang telah terjangkit virus corona, (6) menghargai pengawas dan petugas medis yang merawat pasien virus corona dan mengakui peran mereka dalam menyelamatkan nyawa.

Untuk mengurangi stigma terhadap penyintas COVID-19, dapat dilakukan metode kontak bayangan. Dimana berdasarkan hasil penelitian yang dilakukan oleh Ina dan Dicky (Ratnawulan \& Pelupessy, 2021) terlihat bahwa metode kontak bayangan menunjukkan hasil signifikan untuk merubah pribadi menjadi positif sampai pada respon kognitif, afektif dan perilaku.

Kemudian, pedoman untuk pekerja kesehatan, yaitu (1) mengawasi kesejahteraan emosional dan psikososial sama penting dengan mengawasi kesehatan fisik, (2) menggunakan metodologi adaptasi yang akomodatif, misalnya, menjamin terpenuhinya kebutuhan istirahat dan istirahat selama bekerja atau antara shift, makan makanan yang bergizi dan berkualitas, berpartisipasi dalam kegiatan fisik dan tetap berhubungan dengan orang yang terdekat, tidak menggunakan prosedur coping yang tidak berguna seperti menggunakan tembakau, minuman keras atau obat-obatan lain yang dapat merugikan psikologis dan fisik, (3) beberapa petugas kesehatan mungkin menghadapi penolakan oleh keluarga atau daerah setempat karena prasangka dan takut, jika mungkin tetap berhubungan dengan semua orang di sekitar Anda termasuk melalui teknik-teknik canggih untuk tetap berhubungan, menggunakan cara-cara yang mudah dipahami untuk menyampaikan pesan 
kepada individu-individu yang terampil secara mental, dan individu-individu dengan ketidakmampuan psikososial, (5) menyadari bagaimana menawarkan bantuan kepada individu yang terkena dampak COVID-19 dengan sumber daya yang tersedia sebab ini sangatlah penting bagi mereka yang membutuhkan kesejahteraan psikologis dan dukungan psikososial. Stigma terkait masalah kesehatan mental dapat memicu keraguraguan untuk berpartisipasi atau mencari bantuan untuk COVID-19 dan kondisi kesehatan emosional (WHO, 2020).

Bila kecemasan berubah menjadi ketakutan, perasaan tidak berdaya, panik, maka cara mengendalikan ketegangan dapat dilakukan dengan (1) jangan berusaha menolak perasaan cemas; menolak sensasi ketegangan tidak akan membantu mengurangi tekanan, semakin sedikit menoleransi kecemasan maka akan semakin gugup, (2) jangan hanya memikirkan kabar yang buruk; kecemasan cenderung datang dari informasi negatif, (3) membatasi asosiasi dengan media berbasis web; bergantung dengan media berbasis web sebagai sumber data tentang COVID-19 akan meningkatkan kecemasan sehingga lebih baik masyarakat mendapatkan data dari layanan masyarakat, WHO atau ahli epidemiologi kesehatan masyarakat yang dapat dipercaya, (4) tetap dinamis; olahraga atau refleksi dapat menyeimbangkan sebagian indikasi fisiologis kecemasan, (5) makan teratur dan istirahat sesuai jadwal; upaya menjaga istirahat akan benar-benar membangun kemampuan tubuh untuk beradaptasi dengan tekanan, (6) tetap berhubungan dengan orang yang disayangi (Kemenkes RI, 2020).
Ide-ide yang dapat dilakukan di masa pandemi COVID-19 adalah (1) kegiatan fisik aktif; pekerjaan sehari-hari bermanfaat bagi tubuh dan jiwa, dapat menurunkan hipertensi, membantu mengelola berat badan dan mengurangi resiko penyakit jantung, stroke, diabetes yang dapat meningkatkan kerentanan terhadap virus corona, bermanfaat untuk kesehatan emosional, mengurangi resiko depresi, penurunan intelektual dan menunda demensia, (2) menjaga kesehatan psikologis; ada perubahan signifikan pada jadwal harian yang disebabkan oleh keterbatasan pergerakan sebagai bagian dari upaya untuk mengurangi individu yang terinfeksi virus Corona, menjaga kesehatan mental dengan tetap mengikuti informasi dan mengikuti saran dan arahan dari para ahli kesehatan dan mengikuti saluran berita terpercaya dari WHO, memiliki kegiatan harian atau membuat jadwal baru, membatasi sumber berita yang dapat membuat Anda gelisah atau putus asa, kontak sosial, mencoba untuk tidak menggunakan minuman keras dan obatobatan sebagai cara untuk mengelola ketakutan, kecemasan, kelelahan dan isolasi mandiri, media online dengan membagikan cerita yang baik dan penuh asa, membantu orang lain dan staf kesehatan melalui komuitas untuk berterima kasih kepada mereka dan semua orang yang mengelola COVID-19, (3) berhenti merokok; perokok berisiko lebih tinggi terkena Covid dan berada pada bahaya yang lebih serius menghadapi indikasi ekstrem karena kerja paru-paru terhambat, (4) pengasuhan yang sehat; karena penyebaran penyakit COVID-19 (Coronavirus), anak-anak 
terkena dampak dari jarak fisik, karantina dan pemutusan hubungan sekolah dimana beberapa anak dan remaja merasa terisolasi, gelisah, lelah, khawatir dan sedih karena efek virus ini dapat diperbaiki dengan mengenalkan anakanak dengan konten kreatif yang akan menghibur dan memberikan pengalihan yang benar-benar diperlukan ke pikiran kreatif yang brilian, (5) pola makan yang sehat dengan mengonsumsi sumber makanan berkualitas sangat penting selama pandemi COVID-19, meskipun tidak ada makanan atau peningkatan diet yang dapat mencegah atau menyembuhkan penyakit Coronavirus, pola makan sangat penting untuk membantu sistem kekebalan (WHO, 2020).

Pada dasarnya semua masalah kesehatan psikologis dimulai dengan sensasi cemas (anxiety). Menurut Sadock et al. (Sadock \& Sadock, 2010) kecemasan adalah reaksi terhadap keadaan tertentu yang mengancam, dan merupakan sesuatu yang biasa terjadi. Kegelisahan dimulai dengan keadaan yang mengancam sebagai peningkatan stimulus yang berbahaya (stressor). Pada tingkat tertentu, kecemasan dapat membuat individu lebih waspada terhadap suatu bahaya, sebab bila ancaman tersebut dianggap tidak berbahaya, maka pada saat itu, individu tidak akan melakukan pertahanan diri (self-defence). Dalam menghadapi pandemi virus corona, rasa cemas harus dikelola dengan baik agar tetap memberikan kewaspadaan namun tidak membuat hiruk-pikuk yang ekstrim atau menyebabkan masalah kesehatan emosional yang lebih parah.
Respons cemas akan berbeda untuk setiap orang. Untuk individu tertentu, respons kecemasan umumnya tidak digabungkan dengan respons fisiologis. Namun, pada individu tertentu, kerumitan reaksi dalam kecemasan dapat mencakup respons fisiologis yang sesaat, misalnya denyut nadi menjadi lebih cepat, berkeringat, sakit perut, sakit kepala, merasa gatal, dan gejala lainnya. Setelah individu mulai merasa cemas, kerangka perlindungan diri kemudian akan mempertimbangkan kembali bahaya yang menyertai upaya untuk bertahan hidup, mengurangi atau membunuh perasaan terancam tersebut. Seorang individu dapat memanfaatkan pertahanan diri (defensemechanism) dengan memperluas tindakan intelektual atau motorik.

Cemas biasanya datang dari kesan kejadian yang tidak terkendali, sehingga orang akan memfokuskan diri pada kegiatan yang terkendali (Shin \& Newman, 2019). Sehubungan dengan pandemi ini, contoh kegiatan terkontrol termasuk berolahraga, meditasi, melukis, bermain musik, bercocok tanam, memasak, membaca buku, menonton film, dll. Kegiatan-kegiatan yang berbeda ini sesuai dengan minat dan kapasitas individu sebagai prosedur yang cukup dan defensif untuk mengelola stres, cemas, dan panik (Wood \& Rünger, 2016).

Tahap terakhir dalam mengelola kecemasan adalah menemukan pengaturan beradaptasi (coping) dengan jenis pertahanan diri seperti rasionalisasi. Rasionalisasi tidak dimaksudkan agar tindakan tidak masuk akal menjadi masuk akal, namun merasionalkan. Rasionalisasi tidak dimaksudkan untuk meyakinkan atau mengendalikan orang lain, tetapi 
untuk meyakinkan diri sendiri agar mengakui batas diri sendiri. Misalnya, seorang karyawan yang selama pandemi ini mengurus bisnis dari rumah (work from home) akan membenarkan bahwa ia belum bisa melaksanakan eksekusi yang ideal. Bekerja di rumah selama pandemi tidak hanya memindahkan area kerja. Rasionalisasi bukan untuk orang lain, tetapi untuk tujuan dirinya sendiri, sebagai upaya untuk menjaga kesehatan emosionalnya sehingga tidak menyebabkan frustasi, rasa bersalah, dan perasaan tak berdaya. Hal inilah yang terkadang membuat daya tahan tubuh menurun sehingga mudah bagi virus untuk masuk ke dalam tubuh kita.

Tak hanya itu, ternyata program konseling kelompok juga mampu untuk mengurangi kecemasan yang dialami oleh para pendamping P2TP2A selama masa pandemi corona (Suzanna, Amalia, \& Zahara, 2021).

Informasi pandemi yang tiba-tiba dan terus-menerus akan membuat siapa pun gelisah. Mensurvei tingkat risiko virus Corona melalui penyaringan informasi yang didapat dan kebijakan adalah cara untuk menjaga kecemasan. Informasi dan kebijakan dapat memengaruhi penilaian individu tentang bahaya (COVID-19) dan kemudian memengaruhi reaksi kecemasan yang ditimbulkannya. Beberapa petunjuk untuk menjaga kesehatan mental adalah dengan mengurangi menonton, membaca atau memperhatikan berita yang membuat kecemasan meningkat. Cari data dari sumber terpercaya dan fokuslah untuk membuat pengaturan untuk mengamankan diri Anda dan orang-orang terdekat Anda. Usahakan mencari berita hanya 1-2 kali setiap hari dan pada waktu tertentu. Bila terlalu banyak menerima kabar yang tidak benar, akan membawa kesalahan dalam mengadaptasi coping yang diambil. Mencari data terkait dengan menjaga kesehatan mental selama pandemi di berbagai sumber berbasis internet juga merupakan kemajuan yang positif (Banerjee, 2020). Pilih situs jaringan kesehatan mental yang sah dan dapat dipercaya seperti Kementerian Kesehatan, WHO, biro konsultasi psikologi, atau sumber keagamaan.

Kemudian, hal utama dalam menjaga kesehatan psikologis tidak dapat dipisahkan dari bagaimana individu berhubungan baik dengan Tuhannya. Menjaga lebih dekat dan lebih mengembangkan kepercayaan diri kita dapat bekerja pada kesehatan emosional kita.

\section{SIMPULAN}

Kecemasan adalah hal yang tidak bisa dihindarkan saat berada dalam kondisi yang memprihatinkan, misalnya saat pandemi virus corona. Salah satu kunci penting untuk mengelola kecemasan adalah pemrosesan informasi yang masuk dalam waktu tertentu. Informasi yang didapat harus berasal dari sumber yang terpercaya dan memiliki kredibilitas. Jika Anda mulai merasa memiliki manifestasi masalah mental yang ringan, langkah awal adalah meminta bantuan dari orang yang dipercaya di lingkungan terdekat, bisa kepada pasangan, orang tua, saudara kandung, atau sahabat. Jika ini tidak berhasil, maka minta bantuan dari pihak yang profesional, misalnya, psikolog atau psikiater. Itu adalah jalan keluar yang baik. Beberapa ahli kesehatan emosional seperti Himpunan Psikologi Indonesia 
(HIMPSI) dan Ikatan Psikologi Klinis (IPK) dan fasilitas kesehatan psikologis lainnya menawarkan bantuan berbasis web seperti aplikasi telemedicine atau kunjungan rumah melalui konseling dan psikoterapi.

\section{DAFTAR PUSTAKA}

Banerjee, D. (2020). The COVID-19 Outbreak: Crucial Role the Psychiatrists Can Play. Asian Journal Psychiatr .

Brooks, S. K., Webster, R. K., Smith, L. E., Woodland, L., Wessely, S., Greenberg, N., et al. (2020). The Psychological Impact Of Quarantine And How To Reduce It: Rapid Review Of The Evidence. Lancet , 912-920.

Committee, I. S. (2020). Catatan tentang Aspek Kesehatan Jiwa dan Psikososial Wabah. 120.

Departement of Health Australia. (2017). What is Mental Illness? Diambil kembali dari www.health.gov.au/mentalhealth

Dewi, K. S. (2012). Buku Ajar Kesehatan Mental. Lembaga Pengembangan dan Penjaminan Mutu Pendidikan.

Handayani, Diah, \& dkk. (2020). Penyakit Virus Corona 2019. Jurnal Respirologi Indonesia , 119-129.

Ilpaj, S. M., \& Nurwati, N. (2020). Analisi Pengaruh Tingkat Kematian Akibat COVID-19 Terhadap Kesehatan Mental Masyarakat di Indonesia. Jurnal Pekerjaan Sosial , 16-28.

Kemenkes RI. (2020). Pedoman Dukungan Kesehatan Jiwa dan Psikososial pada Pandemi COVID 19.

Kemenkes RI. (2020). Pedoman Pencegahan dan Pengendalian Corona Virus Disease (Covid19) revisi ke-4. Direktorat Surveilans dan Karantina Kesehatan Sub Direktorat Penyakit Infeksi Emerging .

Liputan6. (2021, Juli 17). Update Covid-19 Sabtu 17 Juli 2021: Positif 2.832.755, Sembuh 2.232.394, Meninggal 72.489. Diambil kembali dari liputan6.com:

https://www.liputan6.com/news/read/4609 327/update-covid-19-sabtu-17-juli-2021positif-2832755-sembuh-2232394meninggal-72489

Putri, A. W., Wibhawa, B., Gutama, A. S., Indonesia, D., Mental, G. K., \& Masyarakat, P. (2015). Kesehatan Mental Masyarakat Indonesia (Pengetahuan dan Keterbukaan
Masyarakat Terhadap Gangguan Kesehatan Mental). 252-258.

Ratnawulan, I., \& Pelupessy, D. C. (2021). Mengurangi Stigma Sosial Terhadap Penyintas Covid-19 melalui Metode Kontak Bayangan. $J-P_{3} K$, 52-6o.

Sadock, B. J., \& Sadock, V. A. (2010). Buku Ajar Psikiatri Klinis Edisi 2. Jakarta: EGC.

Sesilia, A. P. (2020). Kepuasan Pasien Menggunakan Layanan Kesehatan Teknologi (Tele-Health) di Masa Pandemi Covid-19: Efek Mediasi Kualitas Pelayanan Kesehatan. J-P ${ }_{3} K$, 251-260.

Shin, K. E., \& Newman, M. G. (2019). Self- And Other-Perceptions Of Interpersonal Problems: Effects Of Generalized Anxiety, Social Anxiety, And Depression. Anxiety Disord , 1-10.

Sofia, N. A. (2020). Pakar UGM Berikan Tips Cegah Psikosomatis di Tengah Pandemi Covid-19. Diambil kembali dari UGM: https://www.ugm.ac.id/id/berita/199 37pakar-ugm-berikan-tipscegahpsikosomatis-di-tengahpandemicovid-19

Sunarti, E. (2020). Paparan Hasil Survey Ketahanan Keluarga di Masa Pandemi Covid-19.

Suzanna, E., Amalia, I., \& Zahara, C. I. (2021). Program Konseling Kelompok Bagi Pendamping $\mathrm{P}_{2} \mathrm{TP}_{2} \mathrm{~A}$ Aceh Utara Pada Masa Pandemi Covid-19. J-P 3 K , 174-181.

WHO. (2003). Investing in Mental Health. Diambil kembali dari WHO.

WHO. (2020). Looking After Your Physical E Mental Health During Covid-19. Diambil kembali dari WHO: https://www.who.int/campaigns/con necting-the-world-tocombatcoronavirus/healthyathome?gclid= C joKCQiAwMPgBRCzARIsAPWTJ _GbOo8FTWvIGuGUQ3v8VI3Mo WiRjEdj69yRUYnvVoXY327JTW QFEPMaAtNnEALw_wcB

WHO. (2020, March). Mental Health and Psychosocial Considerations During the COVID-19 Outbreak. Diambil kembali dari Mental Health \& COVID-19: https://www.who.int/teams/mentalhealthand-substance-use/covid-19

Wood, W., \& Rünger, D. (2016). Psychology of Habit. Annu , 289-314.

Zed, M. (2014). Metode Penelitian Kepustakaan. Jakarta: Yayasan Obor Indonesia. 